\title{
A NEW WESTERN ATLANTIC SIZE RECORD FOR PTEROIS VOLITANS (ACTINOPTERYGII: SCORPAENIFORMES: SCORPAENIDAE) WITH NEW MORPHOLOGICAL DATA ON HEAD SPINULES
}

\author{
Nicolás R. EHEMANN* \\ Instituto Politécnico Nacional, Centro Interdisciplinario de Ciencias Marinas, La Paz, Baja California Sur,
} Mexico

Ehemann N.R. 2017. Anew western Atlantic size record for Pterois volitans (Actinopterygii: Scorpaeniformes: Scorpaenidae) with new morphological data on head spinules. Acta Ichthyol. Piscat. 47 (0): 297-301.

\begin{abstract}
The red lionfish, Pterois volitans (Linnaeus, 1758), native to the Pacific Ocean has been rapidly colonizing waters of subtropical and tropical western Atlantic. In a decade since its first sighting in the USA it has reached the south-eastern Brazil coast. There are numerous records reporting the sizes of this fish in its nonnative area. Until recently the maximum reported total length was $450 \mathrm{~mm}$. This study describes a specimen from Margarita Island (Venezuela) which was $457 \mathrm{~mm}$ (TL). In addition to its substantial size, the specimen presented and uncommon series of calcified bony spinules at the lacrimal, suborbital, and preopercle ridge-spine of unclear function.
\end{abstract}

Keywords: alien fish, invasive species, lionfish, Caribbean Sea, osteology

The colonization process of the red lionfish, Pterois volitans (Linnaeus, 1758), has been well documented along the Gulf of Mexico and the Caribbean Sea (Chevalier et al. 2008, González et al. 2009, Morris and Akins 2009, Schofield 2009, 2010, Aguilar-Perera and Tuz-Sulub 2010, Lasso-Alcalá and Posada 2010, Ruttenberg et al. 2012, Ferreira et al. 2015, Sandel et al. 2015). Although cytogenetic, molecular, behavioural, and ecological studies of this species have been made (Cure et al. 2012, Nirchio et al. 2014, Coronado-Carrascal et al. 2015, García-Rodríguez et al. 2015), the size ranges reported for this species have not been well documented. The maximum total length of red lionfish reported by Randall et al. (1990) was $380 \mathrm{~mm}$ TL. However, there is no accompanying museum voucher specimen nor data regarding the precise location and time of capture to verify this record. Because numerous aspects of the biology of fish species are related to the size of the individual, the primary purpose of the presently reported results was to determine the maximum size of this species in the western Atlantic populations where it has been reported. The additional task of this paper was to describe for the first time uncommon calcified structure and number of the spinules at the spinal/ridge of three head bones.

A mature male red lionfish (Fig. 1) with a total length of $457 \mathrm{~mm}(388 \mathrm{~mm} \mathrm{SL})$ and weighing 1442 $\mathrm{g}$ was captured by an artisanal fisherman in the coastal waters $\left(11^{\circ} 04^{\prime} 10^{\prime \prime} \mathrm{N}, 64^{\circ} 19^{\prime} 44^{\prime \prime} \mathrm{W}\right)$ off Margarita Island, Venezuela. Using features described by Schultz (1986), this specimen was identified as Pterois volitans (Linnaeus, 1758). To further document this record this specimen was deposited in the Ichthyological Collection of the Museo Marino de Margarita under the catalogue number MMM 1927. Measurements of this specimen were recorded to the nearest $0.01 \mathrm{~mm}$ using digital callipers (Table 1) and a wet weight for the specimen was recorded to the nearest gram using a digital balance. The skin of the head was then subsequently cleaned and removed to expose the configuration of the head bones and described using the osteological terminology of Eschmeyer (1965), Cervigón (1991), Matsunuma and Motomura (2013), and Matsunuma et al. (2016).

Countries in the vicinity of the Gulf of Mexico, the Caribbean Sea, the Greater and Lesser Antilles, have been monitoring lionfish populations over the last decade, and report a size increment for Pterois volitans/miles in the Gulf of Mexico and Caribbean Sea (as reported by different authors over time (Table 2); where these increased sizes may represent a "major ecological trend" that may be confirmed with more intensive monitoring at individual localities. Darling et al. (2011) mentioned a maximum length for $P$. volitans in the Caribbean Sea of $490 \mathrm{~mm}$ based on a personal communication made by James Morris. Another similar case occurred with an unpublished data of 


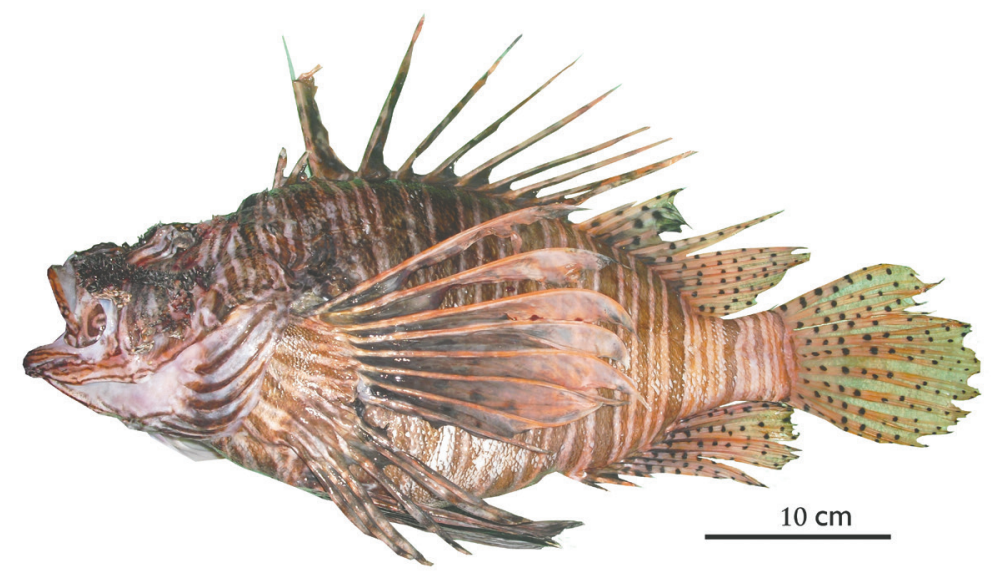

Fig. 1. Mature male specimen of Pterois volitans (457 mm TL) caught from the coastal waters of Margarita Island, Venezuela

Table 1 furthermore owing to the lack of natural predator pressure in

Absolute and relative values of basic biometric characters of the Pterois volitans specimen caught at the Margarita Island, Venezuela

\begin{tabular}{|c|c|c|c|}
\hline & \multirow{2}{*}{ Character } & \multicolumn{2}{|c|}{ Value } \\
\hline & & Absolute & $\%$ in TL \\
\hline \multirow{8}{*}{ 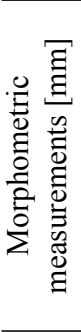 } & Total length & 457.1 & \\
\hline & Standard length & 388.3 & 84.94 \\
\hline & Pre-pectoral fin length & 127.2 & 27.78 \\
\hline & Pre-dorsal fin length & 104.3 & 22.82 \\
\hline & Pre-anal fin length & 235.4 & 51.50 \\
\hline & Post-pectoral fin length & 118.5 & 25.92 \\
\hline & Total height & 154.5 & 33.80 \\
\hline & Head height & 109.4 & 23.93 \\
\hline \multirow{5}{*}{ 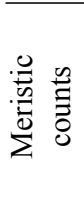 } & Dorsal fin rays & VIII + 11 & \\
\hline & Pectoral fin rays & 14 & \\
\hline & Pelvic fin rays & $\mathrm{I}+5$ & \\
\hline & Anal fin rays & $\mathrm{III}+7$ & \\
\hline & Caudal fin rays & 14 & \\
\hline
\end{tabular}

$\mathrm{TL}=$ total length; Roman numbers denote number of (spiny) rays, while Arabic numbers denote number of soft rays.

a lionfish with a TL of $476 \mathrm{~mm}$ (Morris 2012). Nevertheless both specimens lack information regarding the precise location, year of capture, or museum voucher data. The previous maximum total length reported and confirmed for this species for the western Atlantic was $450 \mathrm{~mm}$ TL, based on a fish caught in 2004 in North Carolina, USA (Muñoz et al. 2011). In the Gulf of Mexico and Caribbean Sea waters a report of $424 \mathrm{~mm}$ TL from a specimen caught in 2009 from the Commonwealth of the Bahamas (Morris and Akins 2009). The Venezuelan specimen (457 mm TL) is by $7 \mathrm{~mm}$ longer or 1.5 percentage points (PP) larger than the USA specimen; $33 \mathrm{~mm}$ longer (7.22 PP larger) compared to the previous Bahamian reported specimen, and $77 \mathrm{~mm}$ longer (16.48 PP larger) than the $380 \mathrm{~mm}$ TL specimen reported by Randall et al. (1990). One biological explanation for this longer specimen could be attributed to feeding activity, where lionfish daily rations and size of prey in the Atlantic is greater than in the native range (Cure et al. 2012), the Atlantic coast. Also these results are congruent with the hypothesis and results obtained previously, given that the population of this species in the Atlantic Ocean grow faster and larger compared to their native Pacific distribution, and that the males of $P$. volitans reach larger sizes than females, (Darling et al. 2011, Morris, 2012, Pusack, 2016).

Beside the fact of reported morphological changes associated with the growth rate, including the increase in numbers of almost all head spines and the number of spinules in many Pterois species (Matsunuma and Motomura 2013), other curious features of this specimen here described are the level of development from the bony ridge and number of spinules (Fig. 2) located at the lacrimal, suborbital and preopercle ridge/spine which is far greater than seen in the majority of other specimen of Pterois volitans (Fig. 3). The precise function of these structures is unknown, but may be associated with the reproduction. This adaptation may provide some competitive advantages over other males at the time of courtship and/or fertilizing the buoyant eggs masses before they ascend to the surface (Fishelson 1975, Morris 2012). Despite the scarce information available today regarding reproductive and matting process of $P$. volitans, there still exists a lack of understanding regarding the biology of this species in the western coast of the Atlantic Ocean. This can be resolved in the future with ethology studies from wild fish populations, through the use of ROV videos and/or the capture of deep-sea specimens, where SCUBA diving and hand collection is not possible.

\section{ACKNOWLEDGEMENTS}

The author is grateful to the fisherman of Playa La Pared, Isla de Margarita for the donation of this specimen. Also very thankful to Dr. Mizuki Matsunuma for his help, guidance, and suggestion regarding the of the cranial osteology identification.

\section{REFERENCES}

Aguilar-Perera A., Tuz-Sulub A. 2010. Non-native, invasive red lionfish (Pterois volitans [Linnaeus, 1758]: Scorpaenidae), is first recorded in the southern 
Table 2

Maximum length of Pterois volitans documented for the Gulf of Mexico and the Caribbean Sea, in a chronological order

\begin{tabular}{cccll}
\hline TL [mm] & SL [mm] & Year & \multicolumn{1}{c}{ Country (locality) } & \multicolumn{1}{c}{ Reference } \\
\hline 450 & & 2004 & North Carolina (USA) & Muñoz et al. 2011 \\
170 & 2007 & Cuba & Chevalier et al. 2008 \\
& 295 & 2008 & Bahamian Archipelago & Darling et al. 2011 \\
424 & & 2009 & Bahamian Archipelago & Morris and Akins 2009 \\
150 & & 2009 & Colombia (San Andrés Island) & González et al. 2009 \\
215 & 2009 & Venezuela & Lasso-Alcalá and Posada 2010 \\
125 & & 2010 & Caymans Islands & Pusack et al. 2016 \\
302 & & 2010 & Turks and Caicos Islands & Claydon et al. 2012 \\
381 & & 2010 & Honduras (Roatán) & Biggs and Olden 2011 \\
137 & 2010 & Mexico (Yucatán) & Aguilar-Perera and Tuz-Sulub 2010 \\
40 & 2010 & Colombia (Bahía Chengue) & Arbeláez and Acero 2011 \\
260 & & 2010 & Colombia (Guajira) & Martínez-Viloria et al. 2011 \\
& 2011 & United States (Florida) & Jud et al. 2011 \\
244 & 2011 & United States (Florida) & Huge et al. 2013 \\
340 & 2011 & Costa Rica & Sandel et al. 2015 \\
385 & 2011 & United States (Florida Keys) & Ruttenberg et al. 2012 \\
265 & 2012 & United States (Gulf of Mexico) & Fogg et al. (2013) \\
280 & 2012 & Colombia (Santa Marta) & Muñoz-Escobar and Gil-Agudelo 2012 \\
377 & 2012 & Colombia (Santa Marta) & Coronado-Carrascal et al. 2015 \\
250 & 2013 & United States (Gulf of Mexico) & Dahl and Patterson 2014 \\
250 & 2013 & Mexico (Tabasco) & Wakida-Kusunoki and Amador del Ángel 2015 \\
$\approx 300$ & 2014 & Brasil (Rio Janeiro) & Ferreira et al. 2015 \\
375 & 2015 & Cuba & García-Rodríguez et al. 2015 \\
457 & 2015 & Mexico (Quintana Roo) & Sabido-Itzá et al. 2016 \\
\hline & & & This study \\
\hline
\end{tabular}

$\mathrm{TL}=$ total length, $\mathrm{SL}=$ standard length.

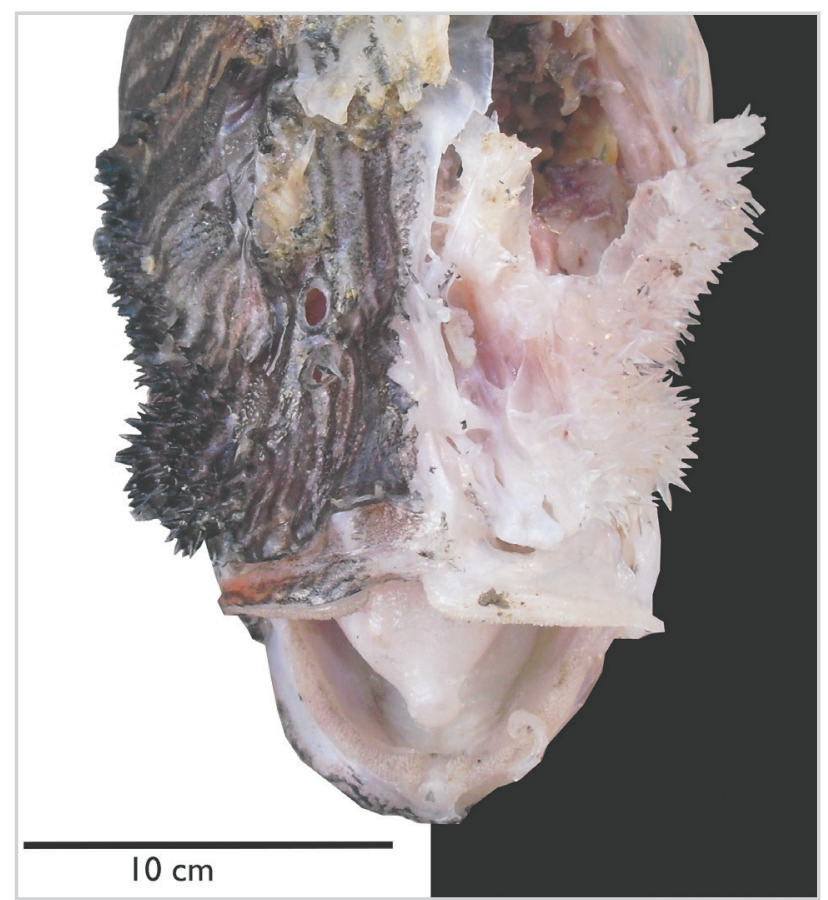

Fig. 2. Dorsal view of the head of the Pterois volitans specimen, showing the level of development of the bony ridge of some of the head bones on both sides

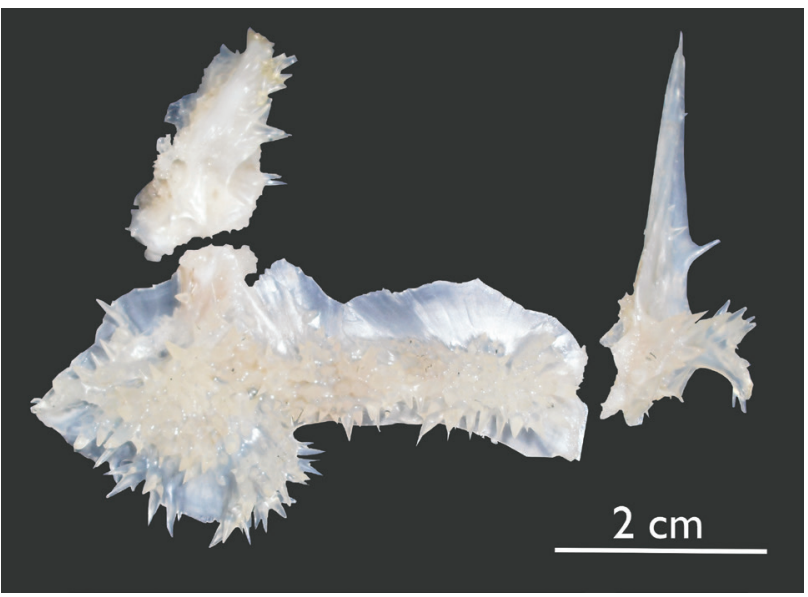

Fig. 3. Development of the bony spinules located at the lacrimal, suborbital, and preopercle ridge/spine from the head bones (the lacrimal and suborbital), may have at least three fused bones referred to in literature as first, second, and third infraorbital bones 
Gulf of Mexico, off the northern Yucatan Peninsula, Mexico. Aquatic Invasions 5 (Suppl. 1): S9-S12. DOI 10.3391/ai.2010.5.S1.003

Arbeláez N.M., Acero A.P. 2011. Presencia del pez león Pterois volitans (Linnaeus) en el manglar de la Bahía de Chengue, Caribe Colombiano. Boletín de Investigaciones Marinas y Costeras 40 (2): 431-435.

Biggs C.R., Olden J.D. 2011. Multi-scale habitat occupancy of invasive lionfish (Pterois volitans) in coral reef environments of Roatan, Honduras. Aquatic Invasion 6 (3): 347-353.

DOI: 10.3391/ai.2011.6.3.11

Cervigón F. 1991. Los peces marinos de Venezuela. Vol. 1. Fundación Científica de Los Roques, Caracas, Venezuela.

Chevalier P., Gutiérrez E., Ibarzábal D., Romero S., Isla V., Calderín J., Hernández E. 2008. Primer registro de Pterois volitans (Pisces: Scorpaenidae) para aguas cubanas. Solenodon 7 (2): 37-40.

Claydon J.A.B., Calosso M.C., Traiger S.B. 2012. Progression of invasive lionfish in seagrass, mangrove and reef habitats. Marine Ecology Progress Series 448: 119-129.

DOI: $10.3354 /$ meps09534

Coronado-Carrascal V., García-Urreña R., Acero A.P. 2015. Comunidad de peces arrecifales en relación con la invasión del pez león: el caso del Caribe Sur. Boletín de Investigaciones Marinas y Costeras 44 (2): 291-302.

Cure K., Benkwitt C.E., Kindinger T.L., Pickering E.A., Pusack T.J., McIlwain J.L., Hixon M.A. 2012. Comparative behavior of red lionfish Pterois volitans on native Pacific versus invaded Atlantic coral reefs. Marine Ecology Progress Series 467: 181-192. DOI: $10.3354 /$ meps09942

Dahl K.A., Patterson III W.F. 2014. Habitat-specific density and diet rapidly expanding invasive red lionfish, Pterois volitans, populations in the northern Gulf of Mexico. PLoS ONE 9 (8): e105852.

DOI: $10.1371 /$ journal.pone.0105852

Darling E.S., Green S.J., O'Leary J.K., Côté I.M. 2011. Indo-Pacific lionfish are larger and more abundant on invaded reefs: A comparison of Kenyan and Bahamian lionfish populations. Biological Invasions 13 (9): 2045-2051.

DOI: $10.1007 / \mathrm{s} 10530-011-0020-0$

Eschmeyer W.N. 1965. Western Atlantic scorpionfishes of the genus Scorpaena, including four new species. Bulletin of Marine Science 15 (1): 84-164.

Huge D.N., Schofield P.J., Jacoby C.A., Frazer T.K. 2013. Total mercury concentrations in lionfish (Pterois volitans/miles) from the Florida Keys National Park Sanctuary, USA. Marine Pollution Bulletin 78 (1-2): 51-55.

DOI: 10.1016/j.marpolbul.2013.11.019

Ferreira C.E.L., Luiz O.J., Floeter S.R., Lucena M.B., Barbosa M.C., Rocha C.R., Rocha L.A. 2015. First record of invasive lionfish (Pterois volitans) for the Brazilian coast. PLoS ONE 10 (4): e0123002.
DOI: 10.1371 journal.pone.0123002

Fishelson L. 1975. Ethology and reproduction of pteroid fishes found in the Gulf of Aqaba (Red Sea) especially Dendrochirus brachypterus (Cuvier), (Pteroidae, Teleostei). Pubblicazioni della Stazione Zoologica di Napoli 39 (Suppl.): 635-656.

Fogg A.Q., Hoffmayer E.R., Driggers W.B.III, Campbell M.D., Pellegrin G.J., Stein W. 2013. Distribution and length frequency of invasive lionfish (Pterois sp.) in the northern Gulf of Mexico. Gulf and Caribbean Research 25 (1): 111-115.

DOI: $10.18785 /$ gcr.2501.08

García-Rodríguez A., Chevalier Monteagudo P.P., Cabrera Sanson E., Caballero Aragón H., Hernández López J.L. 2015. Densidad y biomasa de Pterois volitans/miles (Teleostei: Scorpaenidae) en arrecifes del litoral oeste de La Habana, Cuba. Revista Investigaciones Marinas 35 (1): 21-36.

González J., Grijalba-Bendeck M., Acero A.P., Betancur-R. R. 2009. The invasive red lionfish, Pterois volitans (Linnaeus, 1758), in the southwestern Caribbean Sea. Aquatic Invasions 4 (3): 507-510. DOI: 10.3391/ai.2009.4.3.12

Jud Z.R., Layman C.A., Lee J.A., Arrington D.A. 2011. Recent invasion of a Florida (USA) estuarine system by lionfish Pterois volitans / P. miles. Aquatic Biology 13 (1): 21-26.

DOI: $10.3354 / \mathrm{ab} 00351$

Lasso-Alcalá O.M., Posada J.M. 2010. Presence of the invasive red lionfish, Pterois volitans (Linnaeus, 1758), on the coast of Venezuela, southeastern Caribbean Sea. Aquatic Invasions 5 (Suppl. 1): S53-S59.

DOI: 10.3391/ai.2010.5.S1.013

Matsunuma M., Bogorodsky S.V., Motomura H., Mal A.O. 2016. Objective record of Pterois russelii (Scorpaenidae: Pteroinae) from the Red Sea. Cybium 40 (4): 333-337.

Matsunuma M., Motomura H. 2013. Pterois paucispinula, a new species of lionfish (Scorpaenidae: Pteroinae) from the western Pacific Ocean. Ichthyological Research 62 (3): 327-346.

DOI: $10.1007 / \mathrm{s} 10228-014-0451-6$

Martínez-Viloria H., Rosado-Gómez A., Acero A.P. 2011. Presencia del pez león, Pterois volitans (Actinopterygii: Scorpaenidae), en el departamento de la Guajira, Mar Caribe de Colombia. Boletín de Investigaciones Marinas y Costeras 40 (2): 45-447.

Morris J.A., Akins J.L. 2009. Feeding ecology of invasive lionfish (Pterois volitans) in the Bahamian archipelago. Environmental Biology of Fishes 86 (3): 389-398. DOI: $10.1007 /$ s10641-009-9538-8

Morris J.A.jr. 2012. Invasive lionfish: A guide to control and management. Gulf and Caribbean Fisheries Institute Special Publication Series No. 1, Marathon, FL, USA.

Muñoz R.C., Curryn C.A., Whitfield P.E. 2011. Diet of invasive lionfish on hard bottom reefs of the Southeast USA: Insights from stomach contents and stable 
isotopes. Marine Ecology Progress Series 432: 181193.

DOI: $10.3354 /$ meps09154

Muñoz-Escobar L., Gil-Agudelo D.L. 2012. Composición dietaria del pez león, Pterois volitans (Pisces: Scorpaenidae), en Santa Marta y el Parque Nacional Natural Tayrona. Boletín de Investigaciones Marinas y Costeras 41 (2): 471-477.

Nirchio M., Ehemann N., Siccha-Ramirez R., Pérez J.E., Rossi A.R., Oliveira C. 2014. Karyotype of the invasive species Pterois volitans (Scorpaeniformes: Scorpaenidae) from Margarita Island, Venezuela. Revista de Biología Tropical 62 (4): 1365-1373.

DOI: $10.15517 /$ rbt.v62i4.13029

Pusack T.J., Benkwitt C.E., Cure K., Kindinger T.L. 2016. Invasive red lionfish (Pterois volitans) grow faster in the Atlantic Ocean than in their native Pacific range. Enviromental Biology of Fishes 99 (67): 571-579.

DOI: $10.1007 / \mathrm{s} 10641-016-0499-4$

Randall J.E., Allen G.R., Steene R.C. 1990. Fishes of the Great Barrier Reef and Coral Sea. University of Hawaii Press, Honolulu, HI, USA.

Ruttenberg B.I., Schofield P.J., Akins J.L., Acosta A., Feeley M.W., Blondeau J., Smith S.G., Ault J.S. 2012. Rapid Invasion of Indo-Pacific Lionfishes (Pterois volitans and Pterois miles) in the Florida Keys, USA: Evidence from multiple pre- and postinvasion data sets. Bulletin of Marine Science 88 (4): 1051-1059.

DOI: $10.5343 / \mathrm{bms} .2011 .1108$

Sabido-Itzá M.M., Medina-Quej A., de JesúsNavarrete A., Gómez-Poot J.M., García-Rivas M.C. 2016. La estructura de tallas como evidencia del establecimiento de Pterois volitans (Scorpaeniformes: Scorpaenidae) en el sur del Caribe mexicano. Revista de Biologia Tropical 64 (1): 369-378.

DOI: $10.15517 /$ rbt.v64i1.18943

Sandel V., Martínez-Fernández D., Wangpraseurt D., Sierra L. 2015. Ecology and management of the invasive lionfish Pterois volitans/miles complex (Perciformes: Scorpaenidae) in southern Costa Rica. Revista de Biologia Tropical 63 (1): 213-221. DOI: 10.15517/rbt.v63i1.14749

Schofield P.J. 2009. Geographic extent and chronology of the invasion of non-native lionfish (Pterois volitans [Linnaeus 1758] and P. miles [Bennett 1828]) in the Western North Atlantic and Caribbean Sea. Aquatic Invasions 4 (3): 473-479.

DOI: $10.3391 /$ ai.2009.4.3.5

Schofield P.J. 2010. Update on geographic spread of invasive lionfishes (Pterois volitans [Linnaeus, 1758] and P. miles [Bennett, 1828] in the Western North Atlantic Ocean, Caribbean Sea and Gulf of Mexico. Aquatic Invasions 5 (Suppl. 1): S117-S122. DOI: 10.3391/ai.2010.5.S1.024

Schultz E.T. 1986. Pterois volitans and Pterois miles: two valid species. Copeia 1986 (3): 686-690. DOI: $10.2307 / 1444950$

Wakida-Kusunoki A., Amador del Ángel L.E. 2015. First record of the red lionfish, Pterois volitans, on the coast of Tabasco, Mexico. Primer reporte del pez león, Pterois volitans, en la costa de Tabasco, México. Hidrobiológica 25 (2): 307-309. [In Spanish.]

Received: 1 January 2017 Accepted: 3 May 2017 Published electronically: 30 September 2017 